Int. J. Dev. Biol. 53: 1483-1494 (2009)

doi: $10.1387 / \mathrm{ijdb} .072430 \mathrm{~nm}$

\title{
Ectopic Meis1 expression in the mouse limb bud alters P-D patterning in a Pbx1-independent manner
}

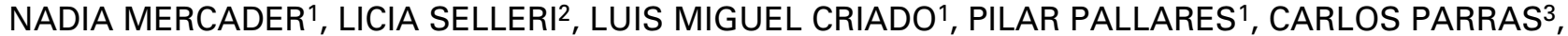 \\ MICHAEL L. CLEARY ${ }^{4}$ and MIGUEL TORRES*,1 \\ ${ }^{1}$ Centro Nacional de Investigaciones Cardiovasculares (CNIC), Instituto de Salud Carlos III, Madrid, Spain, \\ ${ }^{2}$ Department of Cell and Developmental Biology, Cornell University Weill Medical School, New York, USA, \\ ${ }^{3}$ INSERM U711, Université Pierre et Marie Curie, IFR de Neuroscience, Hôpital de la Salpêtrière, Paris, France and \\ ${ }^{4}$ Department of Pathology, Stanford University School of Medicine, Stanford, USA
}

\begin{abstract}
During limb development, expression of the TALE homeobox transcription factor Meis1 is activated by retinoic acid in the proximal-most limb bud regions, which give rise to the upper forelimb and hindlimb. Early subdivision of the limb bud into proximal Meis-positive and distal Meis-negative domains is necessary for correct proximo-distal (P-D) limb development in the chick, since ectopic Meis1 overexpression abolishes distal limb structures, produces a proximal shift of limb identities along the P-D axis, and proximalizes distal limb cell affinity properties. To determine whether Meis activity is also required for P-D limb specification in mammals, we generated transgenic mice ectopically expressing Meis 1 in the distal limb mesenchyme under the control of the Msx2 promoter. Msx2:Meis 1 transgenic mice display altered P-D patterning and shifted P-D Hox gene expression domains, similar to those previously described for the chicken. Meis proteins function in cooperation with PBX factors, another TALE homeodomain subfamily. Meis-Pbx interaction is required for nuclear localization of both proteins in cell culture, and is important for their DNA-binding and transactivation efficiency. During limb development, $\mathrm{Pbx} 1$ nuclear expression correlates with the Meis expression domain, and $\mathrm{Pbx} 1 \mathrm{has}$ been proposed as the main Meis partner in this context; however, we found that $P b x \mathbf{1}$ deficiency did not modify the limb phenotype of Msx2:Meis 1 mice. Our results indicate a conserved role of Meis activity in $\mathrm{P}$-D specification of the tetrapod limb and suggest that $\mathrm{Pbx}$ function in this context is either not required or is provided by partners other than Pbx1.
\end{abstract}

KEY WORDS: mouse limb development, proximo-distal axis, Meis1, Pbx

\section{Introduction}

The vertebrate limb is an excellent model in which to study the genetic control of developmental processes (Capdevila and Izpisua Belmonte, 2001, Tickle, 2002). The mesoderm-ectoderm interactions, cell migrations and patterning events that take place during limb formation involve signaling molecules and transcription factors that also operate during the development of other structures and organs. Learning about the gene regulatory network involved in limb outgrowth will therefore provide valuable insights into developmental processes occurring elsewhere. The limb bud arises from a subset of undifferentiated lateral plate mesoderm (LPM) cells covered by an ectodermal cap, and forms a lateral protrusion from the main anterior-posterior axis of the embryo.
During subsequent growth, cells within the limb bud acquire positional information and translate it into specific patterns of differentiated tissues across the three main limb axes. Along the limb proximo-distal (P-D) axis three main segments are generated: the stylopod (upper arm/leg), zeugopod (lower arm/leg) and autopod (hand-and footplate). These elements arise sequentially during limb outgrowth: elements closer to the trunk (proximal) form first, and the tips of the digits, which lie at the distal-most end of the limb, are the last cartilage element to differentiate (Saunders, 1948, Summerbell et al., 1973).

In the past decade, molecular markers have been character-

Abbreviations used in this paper: AER, apical ectodermal ridge; P-D, proximodistal.

\footnotetext{
*Address correspondence to: Miguel Torres. Centro Nacional de Investigaciones Cardiovasculares, Melchor Fernández Almagro, 3, 28029 Madrid, Spain. Fax:+34-91-453-1304.e-mail: mtorres@cnic.es 


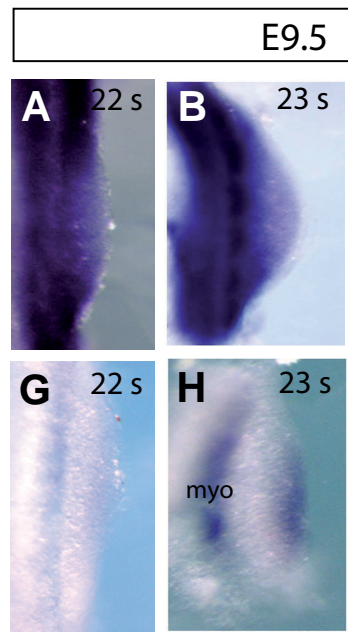

Fig. 1. Comparison of Meis1, Hoxa11 and Hoxa13 expression domains during limb development. Wholemount in situ hybridization with riboprobes for Meis1. Hoxa11 or Hoxa13 as indicated. The figure shows dorsal views of forelimbs (anterior to the top, distal to the right) from stages E9.5, E10, E10.5, E11 and E12.5. For a more precise staging, somite number (s) was counted for the younger embryos.

(A/G), (B/H), ( $\mathbf{J} / \mathbf{N})$ and $\mathbf{( E / K )}$ are forelimbs from the same embryos, with the images in $\mathbf{( G , H , N}, \mathbf{E})$ inverted to enable better comparison of the expression patterns. myo indicates the somite-derived Hoxa11-positive myoblast population migrating into the limb bud.

ized that define the precursor regions of the main P-D segments in the early limb bud. The Hox genes Hoxa11 and Hoxa13 are expressed in the zeugopod and autopod, respectively (Yokouchi, et al., 1991). In the chick, overexpression of Hoxa13 leads to defects in zeugopod cartilage formation and altered cell adhesiveness; the resulting phenotype resembles a change of cell fate towards autopodal cartilage, forming shorter elements than those of the wildtype radius and ulna from the zeugopod (Yokouchi et al., 1995). During development, Hoxa11 and Hoxa13 expression domains partially overlap with those of their Hoxd cluster orthologs (Dollé et al., 1989; Nelson et al., 1996). Double mutants for Hoxa13 and Hoxd13 reveal defects in autopod cartilage formation that suggest additive functions for these two genes (FromentalRamain et al., 1996). Similarly, analysis of Hoxa11/ Hoxd11 double mutant limbs has revealed additive functions for this gene pair during zeugopod development (Davis et al., 1995). These data suggest that Hox function within each P-D segment is achieved by the additive effects of two or more orthologous genes belonging to different Hox clusters. While Hoxa11 and Hoxa13 are the best markers available for zeugopod and autopod, their loss-of-function phenotypes do not support a role in specifying segmental identity in the limb, but rather in determining growth rates and adequate differentiation schedules for each segment (Boulet and Capecchi, 2004).

The expression patterns of members of another homeobox transcription factor (TF) family, the TALE homeobox TFs Meis 1 and Meis2(Moskow et al., 1995, Nakamura et al., 1996), define the proximal-most segments of the limb, including the stylopod and more proximal regions. Meis 1 and Meis2are expressed in the embryonic LPM (Cecconi et al., 1997, Mercader et al., 1999, Oulad-Abdelghani et al., 1997). During limb outgrowth, their expression becomes restricted to a proximal region of the limb bud mesenchyme and ectoderm. When overexpressed throughout the chick limb bud, Meis 1 and 2 each induce alterations in zeugopod and autopod formation (Capdevila etal., 1999, Mercader et al., 1999). The defects observed range from proximalization of the P-D limb axis (Mercader et al., 1999) to deletion of distal segments (Capdevila etal., 1999, Mercader etal., 1999). P-D limb axis proximalization in these studies was evident from the altered distributions of skeletal elements, ectodermal derivatives, muscles and innervation patterns. At the molecular level, the expression of the P-D markers Hoxa11 and Hoxa13 was shifted distally, in correlation with the altered P-D identity of skeletal elements. Meis 1 deficient mice, however, do not display defects in stylopod formation (Azcoitia et al., 2005, Hisa et al., 2004), suggesting functional redundancy between Meis 1 and Meis2, which show overlapping expression in the limb bud.

Meis transcription factors perform their regulatory activity through the formation of heterodimers with other transcription factors, including Hox proteins, other homeobox transcription factors such as engrailed and PDX1, and non-homeodomain transcription factors such as bHLH- and zinc finger-containing proteins (reviewed in Mann and Affolter, 1998). The main cofactors for Meis TFs are members of the PBC subclass of TALE homeobox transcription factors, which comprises the vertebrate Pbx genes and their orthologs extradenticle (exd) from Drosophila and $\mathrm{CEH}-20$ and $\mathrm{CEH}-40$ from C. Elegans (reviewed in Bürglin, 1997).

Four different $P b x$ genes have been characterized (Kamps et al., 1990, Monica et al., 1991, Nourse et al., 1990, Popperl et al., 2000). $P b \times 1$ to 3 are expressed in the mouse limb bud (Capellini et al., 2006, Di Giacomo et al., 2006, González-Crespo et al., 
1998, Selleri et al., 2001). Null mutant mice lacking Pbx1 display malformations affecting the proximal part of the appendages, whereas $P b \times 2$ null mutants develop normally; however, $P b \times\left(^{(-/)}\right)$ $P b \times 2^{(--)}$double mutants completely lack fore- and hindlimbs, and $P b \times 1^{(--)} / P b \times 2^{++-)}$show distal limb defects in addition to proximal malformations (Capellini et al., 2006). In vitro studies support a role for Pbx1 as a molecular and functional partner of Meis proteins that requires Meis for its nuclear import (Capdevila et al., 1999, Mercader et al., 1999, Berthelsen et al., 1999). In the early limb bud, $\mathrm{Pbx} 1$ is expressed in a proximal domain similar to Meis genes, and has been proposed to act as the main Meis cofactor in this region (Capellini et al., 2006, González-Crespo et al., 1998, Mercader et al., 1999).

Here we describe the effects of overexpressing Meis 1 in distal regions of the developing mouse limb. Our results indicate that Meis 1 inhibits distal limb development and promotes proximalization of limb cell fates. Elimination of $P b x 1$ function does not rescue the consequences of Meis 1 overexpression, suggesting either that $\mathrm{Pbx}$ activity is not required for Meis 1 effects on distal limb development or that the activity of other Pbx family members is involved.

\section{Results}

\section{Comparative analysis of Meis1, Hoxa11 and Hoxa13 expres- sion domains}

Molecular markers have been described for the three main limb P-D segments: Meis 1 and Meis2 mark the proximal limb bud regions that give rise to the trunk appendicular structures and the stylopod, Hoxa11 is expressed in the intermediate limb bud regions that form the zeugopod, and Hoxa13labels the autopod precursor region (reviewed in Tabin and Wolpert, 2007). We have performed a detailed comparative analysis of the temporal and spatial dynamics of Meis $1 /$ Hoxa11/Hoxa13 expression during forelimb development. We performed wholemount in situhybridization on wildtype mouse embryos, which were staged according to somite number. To allow direct comparison of marker gene expression domains, embryos were dissected along the midline with a tungsten needle, and left and right halves were respectively hybridized with Meis 1 and Hoxa11 or with Hoxa11 and Hoxa13 (Fig. 1). The forelimb bud can first be observed as a small protrusion from the trunk at E 9.25. Before this stage, the limb bud mesenchyme expresses Meis 1 ubiquitously. We found that the stage at which a Meis 1-negative distal domain can be detected is around the 22 somite (s) stage, corresponding to about E9.5 (Fig. 1A). Hoxa11can barely be detected at this stage (Fig. 1G). During subsequent stages, the distal Meis1-negative domain expands and at the same time a distal domain of Hoxa11 expression appears that approximately occupies the Meis 1-free region (Fig. 1B, C, H, I). The Hoxa11 expression domain expands progressively until E10.5 (Fig. 1J). In the forelimbs of 33s embryos, Hoxa13starts to be expressed in a distal-posterior domain nested within the Hoxa11 expression domain and never overlapping with Meis 1 expression (Fig. 1N). Concomitant with the appearance of Hoxa13, Hoxa11 expression is inhibited in the distal-most portion of the limb, in an area coinciding with the newly formed Hoxa13 domain (Fig. 1K). During the next two days, the Hoxa13 domain expands and by E12.5 marks the clearly visible handplate region; in contrast Hoxa11 expression in E12.5 embryos labels an intermediate segment and Meis 1 is restricted to the proximal-most limb region (Fig. 1F, L, P). Forelimb differentiation has started at this stage of development, and we observe that Meis 1 and Hoxa11expression disappears from the limb bud areas where cartilage elements are condensing. During chicken limb development, an initial overlap in the expression domains of Hoxa11 and Hoxa13proteins has been reported (Sato et al., 2007). We performed in situ hybridization on adjacent limb sections to study the Hoxa13 and Hoxa11

Fig. 2. Detailed analysis of Meis1, Hoxa11 and Hoxa13 expression domains at the onset of Hoxa13 expression. In situ hybridization on adjacent transversal 34 s forelimb sections. Distal is to the left, dorsal to the top. Riboprobes are as indicated on the right of each row. Panels show transverse sections through anterior, medial and posterior limb regions, as indicated at the top of each row. Note that in anterior and posterior sections Hoxa11 and Hoxa13 expression domains overlap, whereas in medial positions, their expression domains are nonoverlapping. 

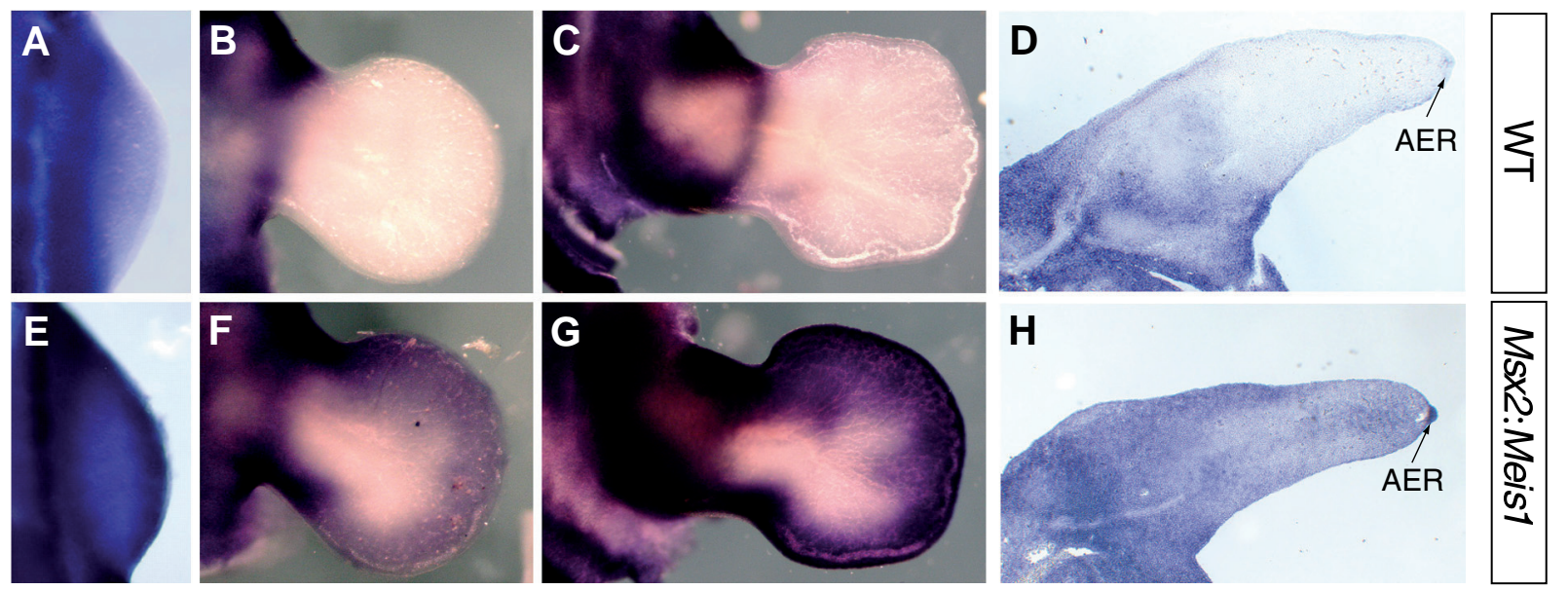

Fig. 3. Ectopic Meis 1 expression in the distal limb bud of $\mathbf{M s x 2 : M e i s} 1$ transgenic limbs. (A,B,C,E,F,G) Wholemount forelimb buds from stages E9.75 (A,E), E11.5 (B,F) and E12.5 (C, G) wildtype (WT) and Msx2:Meis1 transgenic mice hybridized with Meis1 antisense mRNA. Anterior is to the top, distal to the right. (D,H) Meis1 in situ hybridization on transverse sections of E11.5 WT (D) and Msx2:Meis1 (H) limbs. Note ectopic Meis1 expression in the apical ectodermal ridge (AER) in $\mathrm{H}$. Dorsal is to the top, distal to the right.

mRNA expression domains in more detail. At the $34 \mathrm{~s}$ stage, shortly after the onset of Hoxa13expression, we observe overlap in the expression of Hoxa11 and Hoxa13 domains in the posteriormost and anteriormost limb regions, whereas in more medial parts of the limb their domains are mutually exclusive (Fig. 3). At this stage, Meis 1and Hoxa11/Hoxa13expression domains are mutually exclusive throughout the limb bud. Wholemount ISH at later stages indicates mutual exclusion between Meis 1 and Hoxa11 domains, and between Hoxa11 and Hoxa13 domains (Fig. 1 E, F, K, L, O, P). Our results indicate that Hoxa11 and Hoxa13 are transiently co-expressed at least in the anterior and posterior limb regions, while Meis 1 expression does not overlap with either Hoxa11 or Hoxa13 at the stages analyzed.

\section{Alteration of zeugopod and autopod development in Msx2:Meis1 transgenic mice}

Two Meis 1 isoforms have been described: Meis $1 \mathrm{a}$ and Meis $1 \mathrm{~b}$. They differ in their C-terminal domains, which contain transactivation functions as well as TSA and PKA responsive elements. The transactivation capacity and response to TSA and PKA is higher for the Meis1b C-terminus than for the Meis1a Cterminus (Huang et al., 2005). Previous work has shown that Meis1a is the predominant isoform at E10.5 (Azcoitia etal., 2005). We therefore decided to use this isoform for the generation of the transgenic mouse lines. To overexpress Meis 1 in the mouse limb, we generated transgenic mice carrying an insert driving Meis1a expression under the control of the Msx2 promoter. The Msx2 fragment used was a $5.2 \mathrm{~kb}$ upstream sequence, which drives transgene expression in the distal limb bud and AER from E9 onwards (Liu et al., 1994). The phenotypic effect of Meis 1 overexpression was first analyzed in transient transgenic embryos. Embryos derived from injected oocytes were fixed at E14.5 and their skeletal elements were analyzed. Limb defects consisting of hypoplasia, retarded ossification, and dysmorphology or absence of zeugopodal and autopodal skeletal elements were observed in 6 out of 31 transient transgenic embryos (Fig. 4 and Table I; phenotypes are described in detail below). These initial observations prompted us to generate a stable transgenic strain in which to study the phenotype more in detail. Of 13 transgenic founder mice, one transmitted into the germ line.

Ectopic expression of Meis1 mRNA was detected in $84 \%$ $(n=47 / 56)$ of embryos from the stable transgenic line. We observed differences in the levels of ectopic Meis 1expression, even among embryos of the same litter. Around one third of the transgenic embryos displayed higher levels of ectopic Meis 1 expression (data not shown). This difference in gene expression might account for the difference in phenotypic penetrance observed in embryos of $\mathrm{Tg} /+\mathrm{X}+/+$ crosses (see below). We observed that, instead of the proximal restriction found in wildtype embryos (Fig. 3A-C), Meis 1 expression expands into the distal limb bud region in transgenic limb buds (Fig. 3D-F). From E9 to E10.5, the whole limb bud is Meis1-positive (Fig. 3D). Later, ectopic Meis 1 expression in the mesenchyme is confined to a distal portion of the limb bud, underlying the AER (Fig. 3E). At E12.5, ectopic Meis1 can be observed in the AER and the interdigital zones (Fig. 3F). We observed some disparities between the expected expression driven by the Msx2promoter and the actual expression of ectopic Meis 1 observed in the transgenic limb buds. In the chick, we have previously observed that implants of cells overexpressing Meis 1 in the distal limb tend to relocate to more proximal positions (Mercader et al., 2000). A similar phenomenon has also been observed during regeneration of urodele limb appendages (Mercader et al., 2005). The fact that the distribution of Meis 1-positive cells in the distal limb region does not completely fit the MsX2 promoter activity could be a conse-

TABLE 1

\section{DISTRIBUTION OF PHENOTYPES IN MSX2:MEIS1 TRANSGENIC ANIMALS}

\begin{tabular}{lccc} 
Phenotype & $\begin{array}{c}\text { transient } \\
\text { transgenics }\end{array}$ & transgenic line & Tg $\times$ Tg crosses \\
\hline none & $81 \%(25 / 31)$ & $80 \%(35 / 44)$ & $27 \%(16 / 59)$ \\
mild & $10 \%(3 / 31)$ & $11 \%(5 / 44)$ & $17 \%(10 / 59)$ \\
intermediate & $3 \%(1 / 31)$ & $7 \%(3 / 44)$ & $36 \%(21 / 59)$ \\
strong & $6 \%(2 / 31)$ & $2 \%(1 / 44)$ & $20 \%(12 / 59)$ \\
\hline
\end{tabular}


quence of altered adhesive properties of Meis 1-overexpressing cells; however, we do not have direct evidence for this from the present study. Other sites of ectopic Meis 1 expression included the retina, craniofacial mesenchyme, the dorsal roof of the midbrain, the hindbrain, the neural tube, and the ectomesenchyme of the dorsal midline (not shown).

We further investigated the effect of ectopic Meis 1 expression on limb development by analyzing the limb skeletal phenotypes of E17.5 fetuses of the stable line carrying the Msx2:Meis 1 transgene $(\mathrm{Tg})$. Alterations affecting zeugopod and autopod elements were detected in $20 \%$ of embryos obtained from $\mathrm{Tg} /+\mathrm{X}+/+$ crosses and $73 \%$ of embryos derived from $\mathrm{Tg} /+$ inter-crosses (Table I). We classified the observed phenotypes into three classes according to their severity in forelimbs (Table I and Fig. 5). Mild phenotypes mainly affected the zeugopod and were characterized by delayed ossification and moderate anterior bending of the radius (Fig. 5B). Ossification of autopod elements was also slightly delayed in this class. Intermediate phenotypes showed a longer delay in radius ossification and a very notable dysmorphology of this element, which was strongly bent and reduced. The ulna was also reduced and displayed delayed ossification (Fig. 5C). The autopodal phenotype in this class was also characterized by delayed cartilage condensation and ossification, which especially affected anterior digits (Fig. 5C). Finally, strong phenotypes were characterized by an absence of anterior autopod elements. This typically involved the total absence of the anterior carpals, partial or total absence of metacarpal 1 and the complete absence of digit 1 (Fig. 4B, C, D, 5D). Concomitantly, the radius extended into the areas that would normally have been occupied by the missing elements (Fig. 3B, C, D, 5D). Specimens with strong phenotypes also displayed syndactyly of the soft tissues between digits 1 and 2 or 2 and 3 (Fig. 4C and 5D). There is a good correlation between the phenotypes in forelimbs and those observed in hindlimbs, although the hindlimb phenotypes appear to be less severe. The tibia and fibula were reduced in hindlimbs, and, as described for the forelimb, cartilage condensation of the autopod was retarded; however, ectopic condensation of zeugopodal elements or absence of autopodal elements was never observed (Fig. 4B, C, Fig. 5B, C, D). In the progeny of

Fig. 4. Meis1 overexpression interferes with the development of zeugopod and autopod skeletal elements. Limb skeletal preparations of transient Msx2:Meis1 transgenic embryos at E14.5. (A) Wildtype littermate. (B) Example of an Msx2:Meis1 transgenic limb with a strong phenotype. Note the absence of ossification of the radius and tibia (asterisks) and the anterior bending of the radius. Arrowhead in (B) indicates absence of digit 1 cartilage condensations. Arrow marks the deltoid tuberosity of the stylopod, which is unaffected. (C) Close-up views of the distal forelimb of a wildtype littermate and a second Msx2:Meis1 transgenic with a strong phenotype. Note the invasion of the radius into the handplate (asterisk), which is accompanied by reduced formation of digit 1 phalanges. Additionally, this specimen reveals syndactylia of digits 2 and 3 (arrowhead). (D) Schematic representation of defects in distal bone formation observed in Msx2:Meis1 transgenic forelimbs. The ulna is depicted in yellow, the radius in red and the autopod cartilage elements in green. In the presence of ectopic Meis1 expression, invasion of the radius into handplate regions seems to displace anterior autopod elements or interfere with the differentiation wave of autopod cartilage elements, which goes from posterior to anterior. d, digit; fe, femur; fi, fibula; h, humerus; il; ilium; is, ischium; r, radius; t, tibia; u, ulna.
Msx2:Meis 1 heterozygous inter-crosses, there was a high incidence of strong phenotypes (Table I). Although the development of stylopod elements was generally unaffected in Msx2:Meis 1 transgenics, in specimens of the intermediate and strong forelimb phenotypic classes the humerus lacked the deltoid tuberosity (Fig. 5B, C). This phenotype was not observed, however, in any of the transient transgenic specimens (Fig. 4B). We therefore cannot definitively link this stylopod phenotype to Meis 1 overexpression, because it could be an artefactual consequence of the integration site in the single stable transgenic line.

\section{Hoxa11 and Hoxa13 expression in Msx2:Meis1 transgenic embryos}

To analyze the effect of ectopic Meis 1 on limb P-D markers we investigated the expression of the zeugopod and autopod markers Hoxa11 and Hoxa13 in Msx2:Meis1 transgenic limb buds at different stages of limb development. We found that the somite stage at which Hoxa11 and Hoxa13 expression starts is unchanged in Msx2:Meis1 in comparison with wildtype siblings of the same somite number (not shown). At E11, however, the Hoxa11 expression domain was shifted distally in Msx2:Meis1 limbs (Fig. 6A, C). The same effect was observed in E12.5 and
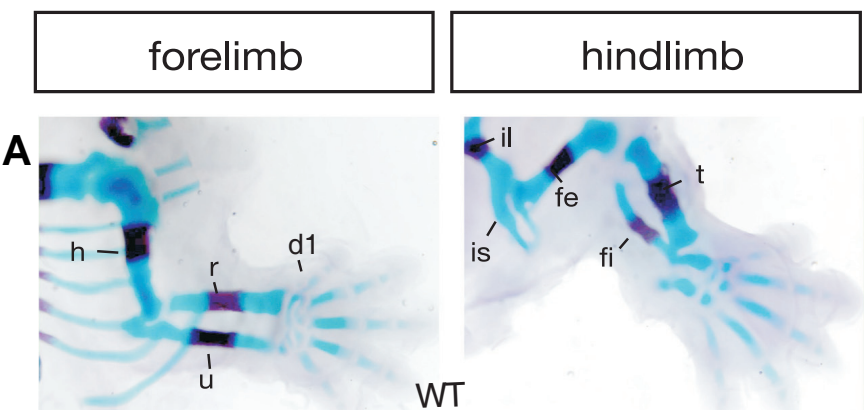

B
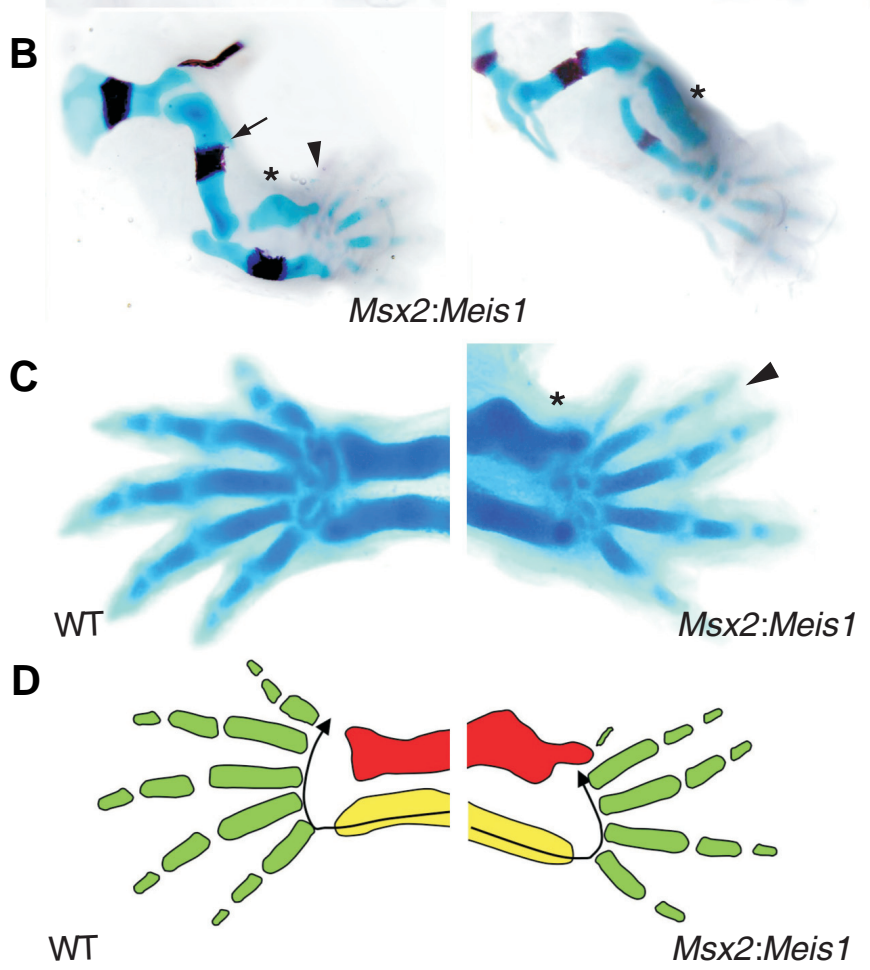

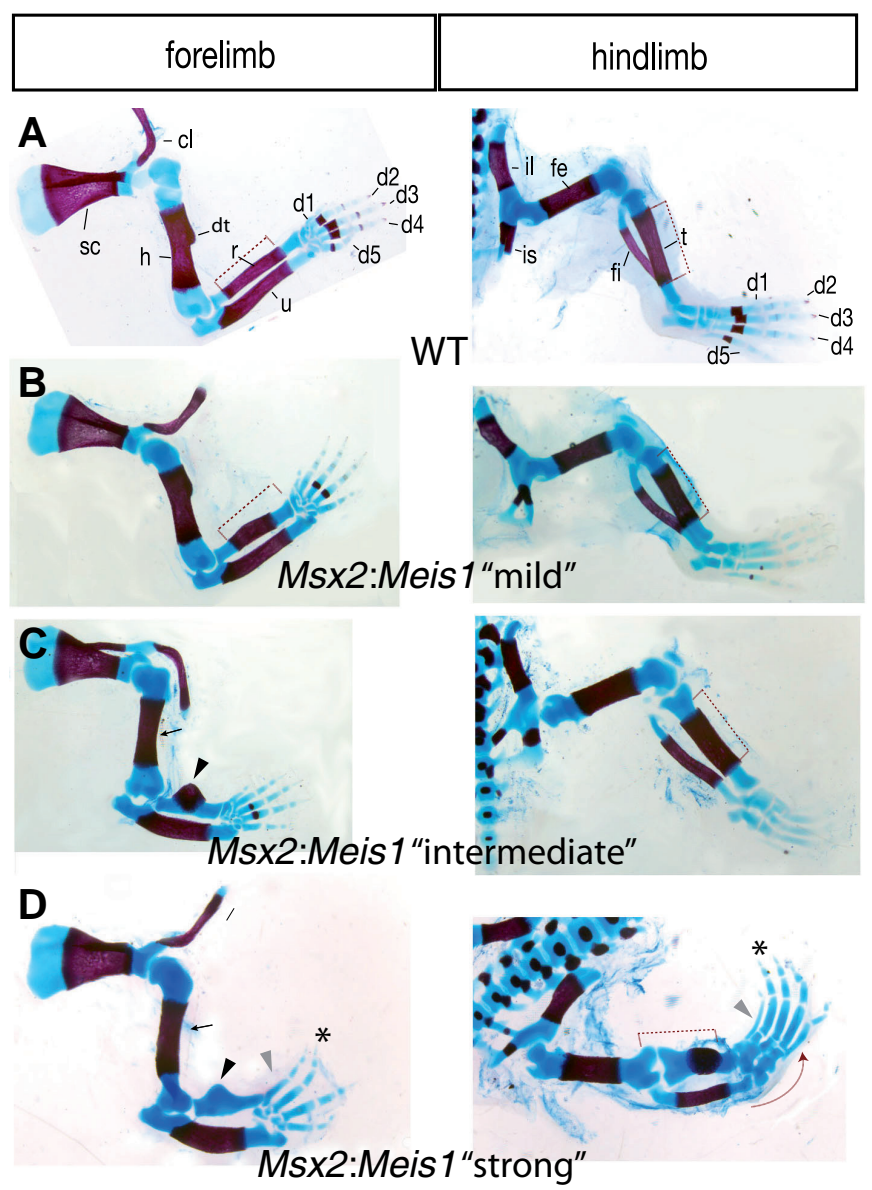

Fig. 5. Defects in distal limb development in a stable Msx2:Meis1 transgenic line. Skeletal preparations of E17.5 wildtype (WT) (A) and Msx2:Meis1 (B,C,D) fore- and hindlimbs. Since the Msx2:Meis1 phenotype showed varying penetrance, embryos were classified into three groups as indicated $(B, C, D)$. (B) Forelimbs of the "mild" phenotype group show reduced ossification of the radius, sometimes accompanied by slight bending. Similarly, hindlimbs show reduced ossification of the tibia compared to same-staged WTs. The red bars are shown to aid comparison of ossified radius length between WT and transgenic limbs. Black arrowheads in (C,D) indicate a strongly reduced or absent radial ossification center and bending of the radius. Grey arrowheads mark missing $d 1$ in the forelimb and strongly reduced $d 1$ in the hindlimb. Asterisks mark fused digits 2 and 3. Arrows highlight missing deltoid tuberosities. Red arrow in (D) indicates a ventral bending of the hindlimb. cl, clavicle; d, digit; dt, deltoid tuberosity; fe, femur; fi, fibula; $h$, humerus; il; ilium; is, ischium; r, radius; sc, scapula; t, tibia; $u$, ulna.

E13 limb buds, with the displacement more evident at the anterior zeugopod/autopod boundary (Fig. 6B, D). Concomitantly, the Hoxa13expression border was displaced distally, especially in its anterior-most region, coinciding with the anterior wrist elements and the metacarpal/digit 1 precursor area, which is the same region in which Hoxa11 shows a more evident distal displacement (Fig. 6E, G). In addition, the Hoxa13 expression signal was slightly fainter overall than in wildtype limb buds (Fig. 6G, H). The reduction in the Hoxa13 expression domain and the shift in the anterior distal border thus correlated with an expansion of the Hoxa11 expression domain towards exactly this region (Fig. 6I-L). This shift in expression, however, occurs in the absence of an overall change of limb morphology at these stages and cannot be attributed to a delay in limb development, because the timing of P-D marker activation remained unchanged (not shown).

\section{Pbx1 loss-of-function does not rescue the Msx2:Meis1 phe- notype}

In all functional contexts studied so far Meis and Pbx transcription factors act in concert to modulate the activity of other transcription factors. The expression pattern of Pbx1 correlates with the Meis 1 proximal limb expression domain, suggesting that $\mathrm{Pbx} 1$ cooperates with Meis 1 during vertebrate limb development. To determine whether the alterations induced by Meis 1 overexpression require interaction with $\mathrm{Pbx1}$, we crossed the Msx2:Meis 1 line into a $P b \times 1$ null mutant line (Selleri et al., 2001), which was backcrossed towards a C57BL/ 6 background. Attenuation of the MsX2:Meis 1 limb phenotype by $P b \times 1$ deficiency would indicate a cooperative action of Meis1 with Pbx1 in the observed alterations of distal limb development.

We performed seven crosses, which yielded a total number of 45 embryos. Embryos were stained with Alcian blue and Alizarin red to visualize limb skeletal elements (Fig. 6). $P b \times A^{(-)}$embryos displayed several malformations affecting the stylopod, such as fused scapula and humerus bones and loss of the deltoid tuberosity of the humerus. Similarly, in the hindlimb the coxae-femur articulation appeared to be fused (Fig. 7B). Compared with the Msx2:Meis 1 line, Msx2:Meis1/Pbx1 crosses showed a reduced intensity of the Meis 1 overexpression phenotype, with only phenotypes of the "mild" class observed. The severity of the mutant phenotypes was similar in Ms $\times 2:$ Meis $1 / P b \times 1^{(--)} \quad(\mathrm{N}=3)$, Ms 2 2:Meis 1/Pbx $1^{++-)}(\mathrm{N}=12)$, and Ms $\times 2:$ Meis $1 / P b \times 1^{+++)}(\mathrm{N}=6)$ limbs (Fig. 7C, D), indicating that it is the genetic background that attenuates the Msx2:Meis 1 phenotype, and not the absence of $P b \times 1$ function per se. These results thus suggest that $P b \times 1$ elimination does not alter the Msx2:Meis 1 phenotype and is thus not required for Meis1-induced distal limb defects.

In the E9.5 murine limb bud, Pbx1 shows a nuclear expression pattern in the proximal limb region corresponding to the Meis expression domain (González-Crespo et al., 1998; Mercader et al., 1999). Immunohistochemistry with antibodies against $\mathrm{Pbx} 1 \mathrm{a}$, $\mathrm{Pbx} 1 \mathrm{~b}$ and a C-terminal motif common to $\mathrm{Pbx} 1, \mathrm{Pbx} 2$ and $\mathrm{Pbx} 3$ did not reveal any clear differences between nuclear Pbx expression domains in wildtype and transgenic limbs at stages between E10 and E11.5 (Fig. 7B, F and data not shown). Thus, in agreement with the results presented above, we found that ectopic Meis 1 expression does not extend the proximal pattern of $\mathrm{Pbx} 1$ nuclear expression into distal limb regions (Fig. 8).

\section{Discussion}

\section{Ectopic Meis1 overexpression interferes with distal limb development}

We have previously shown that Meis 1 is a molecular marker of the stylopod, and that its ectopic expression throughout the chicken limb bud leads to alterations of zeugopod and autopod elements without affecting the development of the proximal limb parts (Mercader et al., 1999). Here we report similar effects on skeletal patterning obtained by overexpressing Meis 1 in the mouse limb primordium. As with the chicken limb, the observed defects include changes to the P-D identity of limb cells, as shown 

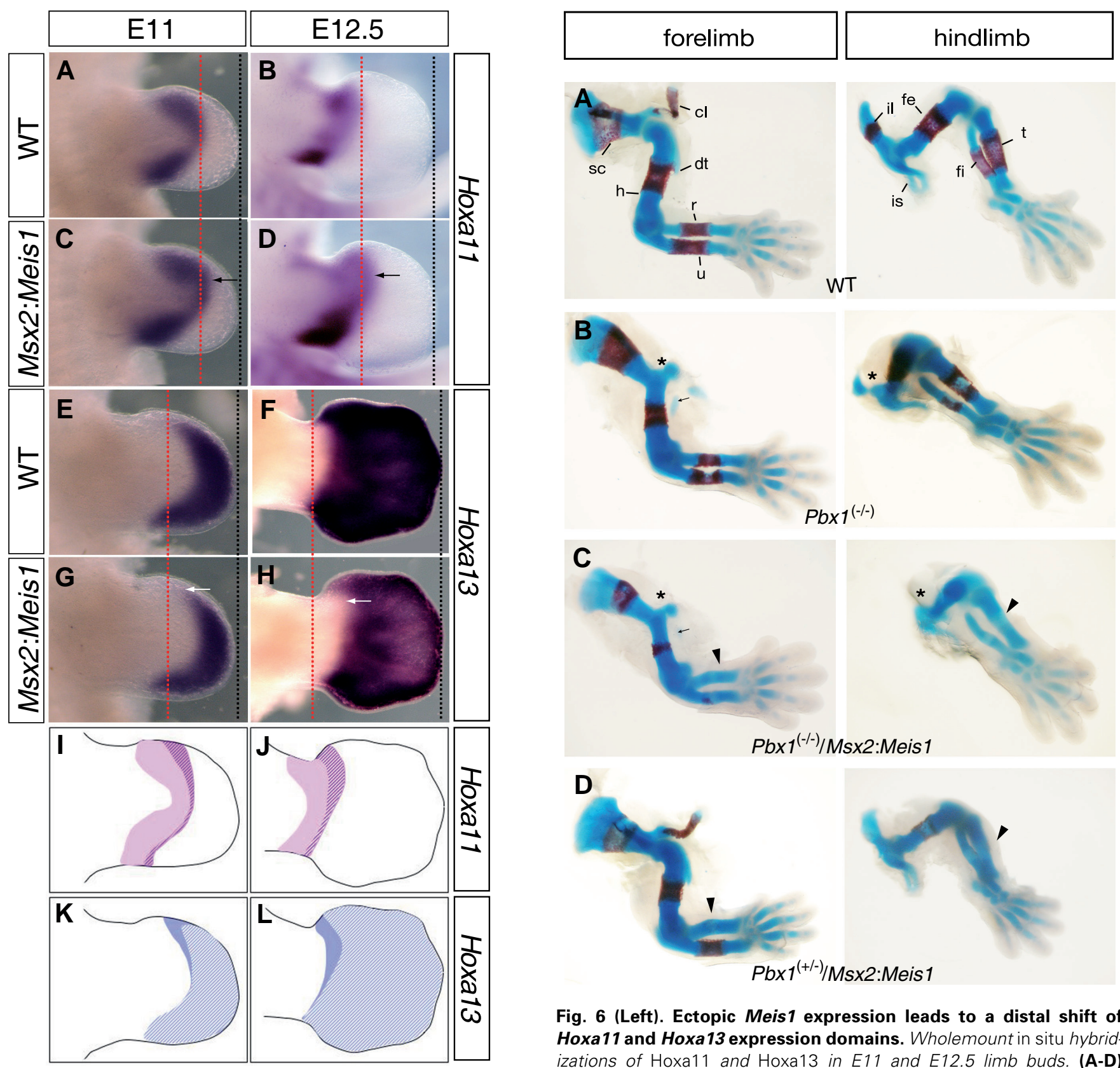

Fig. 6 (Left). Ectopic Meis1 expression leads to a distal shift of Hoxa11 and Hoxa 13 expression domains. Wholemount in situ hybridizations of Hoxa11 and Hoxa13 in E11 and E12.5 limb buds. (A-D) Compared with a wildtype (WT) forelimb (A), the Hoxa11 expression domain in Msx2:Meis1 forelimbs is shifted distally (C, arrow). This distal extension is maintained at later stages of development and is not exclusive to the forelimb, since it is also observed in hindlimb buds at E12.5 (D, arrow). Red dotted lines mark the distal border of the Hoxa11 expression domain in WT limb buds. (E-H) The Hoxa13 expression domain in Msx2:Meis1 limbs is, in contrast, reduced compared with WT littermates. Red dotted lines mark the proximo-anterior Hoxa13 expression limit in WT embryos. Note that this limit is shifted distally in Msx2:Meis1 limbs (white arrows). In all panels, black dotted lines highlight the tip of the limb bud. (I-L) Schematic illustration of the shift in Hoxa11 and Hoxa13 expression domains observed in the presence of ectopic Meis 1 in the distal limb bud. Filled colored areas represent the normal Hoxa11 and Hoxa13 expression domains; striped areas represent Hoxa11/Hoxa13 expression domains in Msx2:Meis1 transgenic limbs. In transgenic limbs the Hoxa11 domain is shifted distally. At the same stages, cells located at the proximal border within the WT Hoxa13 expression domain stop expressing it in the transgenics, thus undergoing a change in proximodistal marker gene expression. The effect is more prominent in the anterior limb bud.

Fig. 7 (Right). Skeletal preparations of $\mathbf{P b x} \mathbf{1}^{(-/) /} / \mathbf{M s x}$ : Meis 1 double mutant fore- and hindlimbs. (A) Skeletal fore- and hindlimb preparations from a wildtype E14.5 sibling. (B) Same-staged preparations of $\mathrm{Pbx} 1^{(-)}$limbs; the forelimbs display fused scapula - humerus joints and the femur is fused to the hip (asterisks). Additionally, the deltoid tuberosity is missing (arrow). (C) Pbx1 ${ }^{(-)}$Msx2:Meis1 limbs still display Pbx ${ }^{(--)}$specific defects and additionally show mild Msx2:Meis1 phenotypes (slightly bent radius and delayed ossification of radius and tibia, arrowheads). (D) Pbx ${ }^{(-/+)}$/ Msx2:Meis1 limbs display features typical of a mild Msx2:Meis1 phenotype, as observed in (C). cl, clavicle; $d$, digit; $d t$, deltoid tuberosity; fe, femur; fi, fibula; h, humerus; il; ilium; is, ischium; r, radius; t, tibia; sc, scapula; $u$, ulna. 
by the altered expression of P-D markers and the extension of limb structures to positions distal to their normal location.

We observed a distal shift of the borders of the two markers that define the zeugopod and autopod, Hoxa11 and Hoxa13(Fig. 6IL). The expression domains of these markers first appear at the postero-distal tip of the limb bud and progressively expand, displacing the borders to more proximal positions. Our results might therefore indicate only a general delay in limb development. Against this possibility, however, we observed that the timing of Hoxa11 and Hoxa13 activation is unchanged in the transgenic embryos. We therefore favor the view that ectopic Meis 1 changes the ability of distal limb cells to progress in distalization. The shift of the expression domains is initially observed across the whole limb bud and affects the proximal Hoxa11 expression border as well as its distal border, which coincides with the proximal limits of Hoxa13expression. At later stages, however, only the anterior areas of the boundary between zeugopod and autopod retain the shifted expression patterns of Hoxa11 and Hoxa13, and it is only around this area that we observed a skeletal condensation pattern compatible with a P-D shift in skeletal elements. Overexpression of Meis 1 in the chick limb bud triggered a very similar alteration at the anterior zeugopodal/autopodal boundary (Mercader et al., 1999), indicating that this area is especially sensitive to alterations in P-D specification mechanisms. This autopodal region is quite unique, as it only expresses one Hox gene, namely Hoxa13. Digit 1 is specifically underdeveloped in mice with one dose of Hoxa13 and is the only digit lost in the complete absence of Hoxa13. Furthermore, a deletion of one copy of the complete Hoxa gene cluster specifically removes only digit 1 (FromentalRamain et al., 1996, Kmita et al., 2005). The fact that the development of the most anterior autopod relies mostly on the

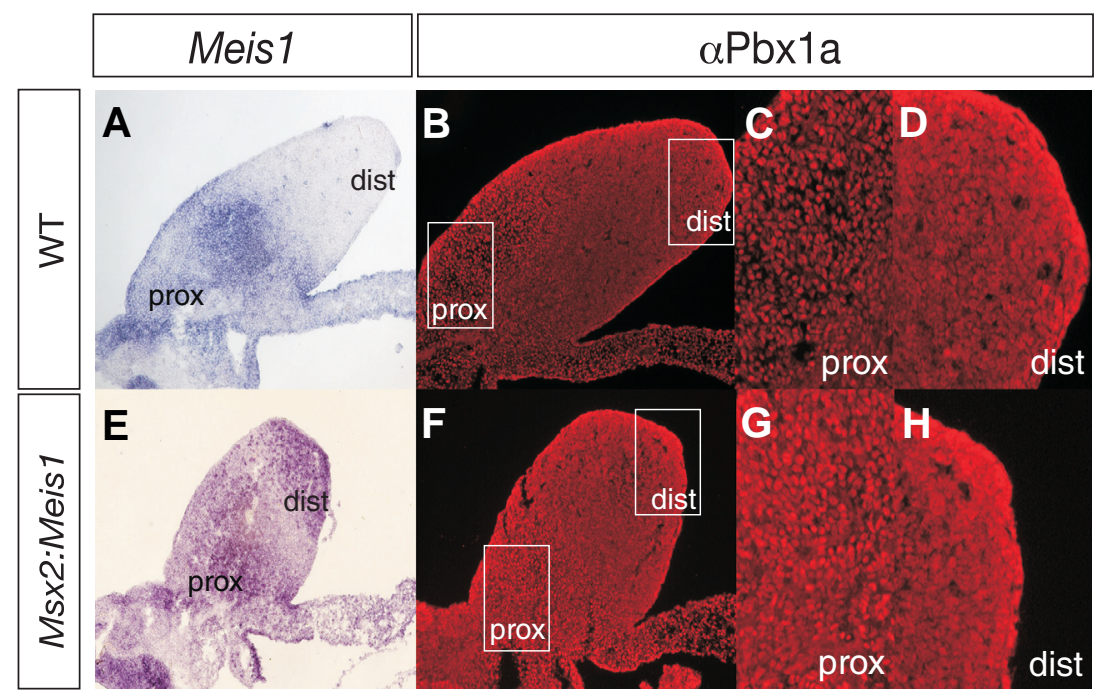

Fig. 8. Overexpression of Meis 1 does not alter $\mathrm{Pbx} 1$ subcellular distribution in the limb bud. Meis1 mRNA in situ hybridization and Pbx-1 immunohistochemistry on adjacent limb cryosections from E10.5 wildtype (A-D) and Msx2:Meis1 transgenic (EH) mice. Anterior is to the left, distal to the top. $(\mathbf{C}, \mathbf{G})$ and $(\mathbf{D}, \mathbf{H})$ are zoomed images of the proximal and distal regions indicated in ( $B$ and F), respectively: dist, distal; prox, proximal. Note that whereas Meis1 expression is ectopically expanded to more distal parts of the limbs (E) in Msx2:Meis1 transgenics, the nuclear pattern of Pbx1 staining was restricted to the proximal limb bud both in wildtypes (B-C) and in transgenic littermates (F-G); no distal expansion of its expression domain could be observed $(\mathbf{D}, \mathbf{H})$. activity of a single Hox gene might underlie the enhanced susceptibility of this region to pattern alterations in general and to Meis 1 gain of function in particular. Some of the effects of Meis 1 overexpression in the distal limb could be in fact explained by the reduction in Hoxa13 expression levels and/or alterations in HoxA13 protein activity, since Hoxa $13^{+/-)}$mice also show fusion digits 2 and 3 (Stadler et al., 2001) and Hoxa13deficient mice show distally-extended Hoxa11 expression in limb buds (Post and Innis, 1999).

During early limb development Meis 1 and Hoxa11 need to establish mutually exclusive domains. Our results may thus reflect a physiological role for Meis 1 in restricting 5' Hox gene expression to distal limb regions, and this Meis 1 function may operate at different levels. Meis/Pbx activity has been shown to regulate the transcription of $\mathrm{Hoxb2}$ by directly modulating the occurs in the limb bud, whereby Meis 1 directly regulates the protein and/or transcriptional activity of Hoxa11 and Hoxa13. vious studies have also demonstrated that a distal limb en5 Hoxd gene expression in the autopod during embryogenesis Spitz et al., 2003). A similar expression control mechanism has been proposed for the Hoxa cluster (Lehoczky et al., 2004). could be caused by an influence of Meis 1 activity on the distal limb

In addition to the observed alterations to the establishment of $\mathrm{P}-\mathrm{D}$ identities, the limbs of Meis 1 transgenic mice show defects in bone growth and differentiation. It is important to note that during normal development Meis expression is downregulated in chondrogenic centres. Therefore, the alterations in bone differentiation observed after Meis 1 overexpression could be due to a direct counteraction of this process by Meis activity. However, if this was the case, we would expect to see alterations in bone formation within all P-D limb segments after Meis 1overexpression, which is not observed. Overexpression of Meis 1 in the chick induces bone differentiation defects only in the skeletal elements of the distal limb; the stylopod was unaffected. This suggests that the alterations in bone differentiation derive from misspecification of skeletal elements rather than from an interference of Meis activity with the ossification program. The results reported here support this hypothesis, as Meis 1overexpression in Msx2:Meis 1 transgenic mouse limb buds is specific for undifferentiated cells, there being therefore no Meis 1 overexpression during skeletal element differentiation. Under these conditions the transgenic Msx2:Meis1 mice reproduce the distal-specific growth and differentiation defects observed in the chick. This indicates that these defects are caused by alterations early in the specification process, when cells are still in the undifferentiated area under the influence of the AER. Thus the provision of altered positional cues to precursors of the primary chondrogenic centers may result in alterations of 
the differentiation program that only become apparent during the subsequent growth and differentiation phase. Similar observations have been reported after the modification of Hox gene activity. 5 Hoxdand 5 Hoxagenes are expressed at specific A-P and P-D positions of the limb bud (Dollé et al., 1989, Nelson et al., 1996, Yokouchi et al., 1991). At the onset of cartilage condensation, Hoxgene expression becomes downregulated (Suzuki and Kuroiwa, 2002). Nevertheless, gain or loss of function in Hoxgene activity leads to position-specific defects in bone differentiation, suggesting that early misspecification leads to differentiation defects (Davis and Capecchi, 1996, Fromental-Ramain et al., 1996, Goff and Tabin, 1997, Morgan et al., 1992, Zakany and Duboule, 1999).

Hoxd13and Hoxd12 misexpression in the limb bud interferes with the correct development of zeugopodal elements of chicken and mouse embryos, respectively (Goff and Tabin, 1997, Knezevic et al., 1997). Hoxd13 overexpression leads to shorter tibia and fibula bones and Hoxd12gain-of-function in the posterior lateral plate mesoderm leads to hemimelia of the tibia. Similarly, missexpression of another distal Hoxgene, Hoxa13, also leads to development of shorter zeugopodal elements (Yokouchi et al., 1995). A possible explanation is that these Hoxgenes, which are predominantly or exclusively expressed in the autopod region, interfere with the Hoxgene of protein function within the zeugopod when overexpressed. Hoxd13/a13/d12 might interfere with the function of other Hoxgenes such as Hoxd11 and Hoxa11, which have been shown to control zeugopod development (Davis et al., 1995). Given that Meis1 overexpression causes zeugopodal defects that partially resemble those found in Hoxd13, Hoxd12or Hoxa13overexpression, but does not activate these distal genes in the autopod, it might act in this context by interfering with the correct Hox protein function in the zeugopod.

In the proximal limb, Meis1 expression is promoted by RA, which has been proposed as a determinant of proximal limb identities (Mercader et al., 2000b, Ribes et al., 2007, Yashiro et al., 2004). The phenotype obtained after Meis 1 overexpression partially resembles the teratogenic effects of RA on limb development (Sucov et al., 1995, Yashiro et al., 2004). A closely related gene of the Meis family, Meis2 (Cecconi et al., 1997, OuladAbdelghani et al., 1997), is coexpressed with Meis1 during proximal limb development, is also regulated by RA and probably performs redundant roles with Meis 1. We therefore suggest that Meis 1 and Meis2might be important mediators of the RA function and teratogenic effects during limb P-D specification.

\section{Meis proteins might act independently of a Pbx cofactor}

The TALE homeobox proteins Meis and Pbx have been shown to form heterodimers and to act as a functional unit in several species and cellular contexts. The nuclear localization of these proteins has also been shown to be interdependent (Abu-Shaar et al., 1999, Berthelsen et al., 1999, Capdevila et al., 1999, Mercader et al., 1999, Rieckhof et al., 1997). In Drosophila, the $\mathrm{Pbx}$ ortholog EXD translocates to the nucleus only in presence of the Meis ortholog HTH. In other species, however, the role for nuclear transport seems to be switched between Meis and Pbx proteins (Maeda et al., 2002, Prpic et al., 2003, Vlachakis et al., 2001). For example, in the spider, exdis expressed exclusively in the proximal limb, whereas hth is expressed throughout the appendage; however, HTH is localized in the nuclei only of proximal cells, and shows cytoplasmic expression in distal regions. Similarly, during hindbrain development in the zebrafish, $\mathrm{Pbx} 4$ regulates nuclear transport of Meis3 (Choe etal., 2002). We previously reported that $\mathrm{Pbx} 1$ nuclear expression is limited to a proximal limb region that coincides with the Meis expression domain (González-Crespo et al., 1998). A distal cytoplasmic signal detected with anti-Pbx1 antibody was then interpreted as indicating the presence of cytoplasmic Pbx1 protein in the distal limb. A recent report, however, showed restriction of Pbx1 transcripts to the proximal limb (Capellini etal., 2006), suggesting that the cytoplasmic antibody staining for Pbx1 in the distal limb was unspecific. We have now tested this by comparing the distal limb cytoplasmic staining between WT and Pbx1-deficient embryos at E11.5 and found that indeed the distal cytoplasmic signal observed at this stage is unrelated to $\mathrm{Pbx} 1$ protein (not shown). Nonetheless, activation of nuclear $\mathrm{Pbx}$ in the distal limb bud, detected with an antibody to $\mathrm{Pbx} 1,2$, and 3, was reported after ectopic PKA activation (Kilstrup-Nielsen et al., 2003). In order to determine whether ectopic Meis1 activity in the Msx2:Meis1 transgenic line might lead to a similar distal expansion of nuclear $\mathrm{Pbx}$ expression in the limb bud, we analyzed the changes in $\mathrm{Pbx}$ antibody staining. However, Pbx expression was unaffected, suggesting that additional signaling events, such as PKA signaling, are required to ectopically express $\mathrm{Pbx}$ in distal limb domains.

Finally, we found that elimination of $P b \times 1$ does not rescue the Meis 1 overexpression phenotype, indicating either that Meis 1 is able to perturb P-D limb specification in the absence of any $\mathrm{Pbx}$ function or that ectopic Meis1 recruits other $\mathrm{Pbx}$ proteins to produce this overexpression phenotype. Other $P b x$ genes expressed in the developing limb include $P b \times 2$ and $P b \times 3$ (Capellini etal., 2006, Di Giacomo et al., 2006). While Pbx3is not expressed in all limb regions at the relevant stages, $P b \times 2$ is expressed throughout the limb bud during the P-D specification phase and is functionally involved in both proximal and distal limb patterning together with Pbx1 (Capellini et al., 2006). We cannot, therefore, rule out an interaction between $\mathrm{Pbx} 2$ and Meis 1 in the generation of the Meis 1 overexpression phenotype. Functional studies involving crosses of Msx2:Meis1 transgenics into the Pbx2 null mutant line will hopefully answer this question in the future.

\section{Materials \& Methods}

\section{Generation of Msx2:Meis1 transgenic lines}

A full-length Meis 1a cDNA fragment was cloned into the EcoRI and Sacl sites of the PPGKneobpA expression vector. A + $0.52 \mathrm{~kb} M s \times 2$ promoter fragment was inserted at the EcoRI site upstream of the Meis 1a ATG start codon. A larger fragment of the Msx2 promoter was subsequently cloned into Spel/Xhol restriction sites, to yield a total promoter length of $5.2 \mathrm{~kb}$.

For injection, the plasmid was linearized with Xhol followed by purification by electroelution. The plasmid was further purified by three phenol extractions followed by three ether extractions. The plasmid was ethanol precipitated successively three times and resuspended in Tris-EDTA buffer (7mM Tris $\mathrm{pH} 7.4 ; 0.2 \mathrm{mM}$ EDTA). As a last step, the plasmid was purified by dialysis for $72 \mathrm{~h}$.

Transient transgenic embryos were generated by microinjecting the linearized construct into fertilized C57/BL6 oocytes. A transgenic mouse strain was derived from one of the founder animals; these animals have the characteristic Meis 1-overexpression phenotype of shortened forelimbs with digits 2 and 3 fused.

The Msx2.Meis 1stable transgenic line was generated on a C57B6CBA 
genetic background and subsequently backcrossed into C57B6 for six generations. Embryos from generations $F 1$ to $F 6$ were used for these studies.

For genotyping, genomic DNA was extracted from mouse tails or embryonic vitelline membranes. RT-PCR was performed using primers tg-Forward: GAC GAC CTA CCC CAT TAT and tg-Reverse: CTC TCT GGC TCC CTT CCT ACT. As a further control, embryo heads were hybridized with Meis 1 to detect ectopic Meis 1 expression in midline and branchial arches of Msx2:Meis1 embryos.

To generate Msx2:Meis1/Pbx1 (-/-) mutant embryos, Msx2:Meis1 transgenic mice displaying a strong phenotype were crossed with $\mathrm{Pbx} 1(+/$ -) mice. Littermates from seven crosses $(n=45)$ were genotyped and processed for cartilage staining.

\section{In situ hybridization}

Embryos were fixed overnight in 4\% paraformaldehyde (PFA). Wholemount in situ hybridization was performed as described (Wilkinson and Nieto, 1993). For in situ hybridization on sections, fixed embryos were transferred to $30 \%$ sucrose in PBS and embedded in OCT. Cryosections (10 to $15 \mu \mathrm{m}$ ) were collected on Superfrost slides and allowed to air-dry for $2 \mathrm{~h}$. Before hybridization, slides were washed for $5 \mathrm{~min}$ with PBS and refixed for $10 \mathrm{~min}$ with $4 \%$ PFA. Slides were washed for $5 \mathrm{~min}$ in PBS and prehybridized for $5 \mathrm{~min}$ at $65^{\circ} \mathrm{C}$ in prehybridization buffer (50\% formamide, $1 \times$ SSC pH 4.5, 1\% SDS). For each slide, $2 \mu$ riboprobe reaction mix was diluted in $100 \mu \mathrm{l}$ hybridization buffer $(11.4 \mathrm{~g} \mathrm{NaCl}, 1.4 \mathrm{~g}$ Tris- $\mathrm{HCl} \mathrm{pH}$ 7.5, $0.134 \mathrm{~g}$ Trisbase, $5 \mathrm{mM} \mathrm{NaH}_{2} \mathrm{PO}_{4} .2 \mathrm{H}_{2} \mathrm{O}, 5 \mathrm{mM} \mathrm{Na}_{2} \mathrm{HPO}_{4}, 0.05 \mathrm{M}$ EDTA, $50 \%$ formamide, $10 \%$ dextran sulfate, $1 \mathrm{mg} / \mathrm{ml}$ tRNA, $1 \times$ Denhardt's solution). After overnight hybridization at $70^{\circ} \mathrm{C}$, slides were transferred to a slide rack and placed in a jar containing preheated posthybridization buffer (50\% formamide, $1 \times$ SSC pH 4.5, 1\% SDS). After two $30 \mathrm{~min}$ washes at $65^{\circ} \mathrm{C}$, the rack was cooled to room temperature (RT) and slides washed twice for $30 \mathrm{~min}$ in MABT $(100 \mathrm{mM}$ maleic acid, $150 \mathrm{mM} \mathrm{NaCl}$, $0.1 \%$ Tween20, $\mathrm{pH} 7.5$ ). Prior to antibody incubation, sections were blocked for $1 \mathrm{~h}$ at RT in blocking solution ( $2 \%$ blocking reagent (Roche) and $20 \%$ goat serum in MABT). For antibody incubation, anti-DIG-AP (Roche) was diluted $1 / 2000$ in blocking solution and $200 \mu$ l were added per slide. Slides were incubated overnight at RT, and then washed $5 \times 20$ min at RT in MABT. Slides were next washed $2 \times 10$ min with gentle rocking in AP buffer (100 mM Tris HCL pH 9.5; $150 \mathrm{mM} \mathrm{NaCl}, 50 \mathrm{mM}$ $\mathrm{MgCl}_{2 ;} 0.1 \% \mathrm{Tw} 20 ; 0.5 \mathrm{mg} / \mathrm{ml}$ levamisol). For the staining reaction, $200 \mu \mathrm{l}$ BM Purple staining solution (Roche) were added to each slide. The staining reaction required from a few hours to 2 days. When necessary, the staining solution was replaced every $12 \mathrm{~h}$. The reaction was terminated by a rapid rinse in $\mathrm{H}_{2} \mathrm{O}$, and slides were mounted in Aquatex (Merck). For probe synthesis of Hoxa11 and Hoxa13, PCR products comprising sequences between ( $-25 \mathrm{bp}$ to $+506 \mathrm{bp})$ and $(-541 \mathrm{bp}$ to +478 $\mathrm{bp}$ ) respectively were used as templates. Meis 1 a riboprobe spanned the sequence between 814 bp and $2119 \mathrm{bp}$.

\section{Immunohistochemistry}

For cryosectioning, embryos were fixed overnight in 4\% PFA, soaked overnight in 30\% sucrose/PBS solution and embedded in OCT. $12 \mu \mathrm{m}$ sections were collected on Fisher Superfrost slides. Sections were airdried for $30 \mathrm{~min}$ and refixed in ice-cold acetone for $2 \mathrm{~min}$ at $4^{\circ} \mathrm{C}$. Slides were then immediately transferred to a jar containing $0.1 \%$ Tween 20 in PBS (PBT) and washed three times for 5 min each. Permeabilisation was increased by a 10 min wash in $0.05 \%$ TritonX-100 in PBS. Sections were preincubated for 1 hour at RT in blocking buffer (10\% goat serum in PBT) and incubated overnight in primary antibody diluted in $2 \%$ goat serum in PBT. Sections were then washed three times for $5 \mathrm{~min}$ in PBT. The secondary antibody was biotin conjugated anti-rabbit and the tertiary antibody was Streptavidin-Cy3 conjugated. Between antibody incubations, slides were washed for $15 \mathrm{~min}$ in PBT with at least three changes. The anti-Pbx1 and anti-Pbx123 antibodies were from Santa Cruz Biotechnology Inc. (references P-20 and C-20, respectively), and the anti-Pbx1a and anti-Pbx1b antibodies were provided by G.H. Swift.

\section{Skeletal preparations}

Embryos were eviscerated and the skin removed. After overnight fixation in $95 \%$ ethanol, embryos were stained overnight in Alcian blue solution ( $150 \mathrm{mg}$ Alcian blue (SIGMA), $800 \mathrm{ml} 98 \%$ ethanol, $200 \mathrm{ml}$ acetic acid). After several further hours in $95 \%$ ethanol, embryos were transferred to $2 \% \mathrm{KOH}$ for $24 \mathrm{~h}$. After overnight staining in Alizarin red solution (50mg/l Alizarin red (SIGMA) in $2 \% \mathrm{KOH}$ ), skeletons were cleared in $1 \%$ $\mathrm{KOH} / 20 \%$ glycerol and stored in $50 \%$ ethanol $/ 50 \%$ glycerol solution.

\section{Acknowledgements}

We are grateful to $R$. Maxson for the Msx2 promoter constructs and $N$. Copeland for the Meis1a full-length CDNA. Anti-Pbx1a and anti-Pbx1b were kindly provided by G.H.Swift. We are grateful to Terence Capellini for providing material and helpful discussions. We thank Simon Bartlett for text editing and Alberto Roselló for critical reading of the manuscript. We thank members of the animal house Santiago Rodriguez, José María Fernández and David Esteban for maintaining the Msx2:Meis1 line. This work was supported by a grant from the Spanish Ministry of Science and Education (BFU2006-10978/BMC). N.M. was supported by Marie Curie fellowship 83EU-056147 and currently by RYC-2006-001694 contract. The CNIC is supported by the Spanish Ministry of Health and Consumer Affairs and the Pro-CNIC Foundation.

\section{References}

ABU-SHAAR, M., RYOO, H.D. and MANN, R.S. (1999). Control of the nuclear localization of extradenticle by competing nuclear import and export signals. Genes Dev 13: 935-45.

AZCOITIA, V., ARACIL, M., MARTINEZ, A.C. and TORRES, M. (2005). The homeodomain protein Meis1 is essential for definitive hematopoiesis and vascular patterning in the mouse embryo. Dev Bio/280: 307-20.

BERTHELSEN, J., KILSTRUP-NIELSEN, C., BLASI, F., MAVILIO, F. and ZAPPAVIGNA, V. (1999). The subcellular localization of PBX1 and EXD proteins depends on nuclear import and export signals and is modulated by association with PREP1 and HTH. Genes Dev 13: 946-53.

BOULET, A.M. and CAPECCHI, M.R. (2004). Multiple roles of Hoxa11 and Hoxd11 in the formation of the mammalian forelimb zeugopod. Development 131: 299309.

BÜRGLIN, T.R. (1997). Analysis of TALE superclass homeobox genes (MEIS, PBC, KNOX, Iroquois, TGIF) reveals a novel domain conserved between plants and animals. Nucleic Acids Res 25: 4173-80.

CAPDEVILA, J. and IZPISUA BELMONTE, J.C. (2001). Patterning mechanisms controlling vertebrate limb development. Annu Rev Cell Dev Biol17: 87-132.

CAPDEVILA, J., TSUKUI, T., RODRIQUEZ ESTEBAN, C., ZAPPAVIGNA, V. and IZPISUA BELMONTE, J.C. (1999). Control of vertebrate limb outgrowth by the proximal factor Meis2 and distal antagonism of BMPs by Gremlin. Mol Ce//4: 839-49.

CAPELLINI, T.D., DI GIACOMO, G., SALSI, V., BRENDOLAN, A., FERRETTI, E., SRIVASTAVA, D., ZAPPAVIGNA, V. and SELLERI, L. (2006). Pbx1/Pbx2 requirement for distal limb patterning is mediated by the hierarchical control of Hox gene spatial distribution and Shh expression. Development 133: 2263-73.

CECCONI, F., PROETZEL, G., ALVAREZ-BOLADO, G., JAY, D. and GRUSS, P. (1997). Expression of Meis2, a Knotted-related murine homeobox gene, indicates a role in the differentiation of the forebrain and the somitic mesoderm. Dev Dyn 210: 184-90.

CHOE, S.K., VLACHAKIS, N. and SAGERSTROM, C.G. (2002). Meis family proteins are required for hindbrain development in the zebrafish. Development 129: 585-95.

DAVIS, A.P. and CAPECCHI, M.R. (1996). A mutational analysis of the 5' HoxD genes: dissection of genetic interactions during limb development in the mouse. Development 122: 1175-85.

DAVIS, A.P., WITTE, D.P., HSIEH-LI, H.M., POTTER, S.S. and CAPECCHI, M.R (1995). Absence of radius and ulna in mice lacking hoxa-11 and hoxd-11. Nature 
375: 791-5.

DI GIACOMO, G., KOSS, M., CAPELLINI, T.D., BRENDOLAN, A., POPPERL, H. and SELLERI, L. (2006). Spatio-temporal expression of $\mathrm{Pbx} 3$ during mouse organogenesis. Gene Expr Patterns 6: 747-57.

DOLLÉ, P., IZPISÚA-BELMONTE, J.C., FALKENSTEIN, H., RENUCCI, A. and DUBOULE, D. (1989). Coordinate expression of the murine Hox-5 complex homoeobox-containing genes during limb pattern formation. Nature 342: 76772.

FROMENTAL-RAMAIN, C., WAROT, X., MESSADECQ, N., LEMEUR, M., DOLLE, P. and CHAMBON, P. (1996). Hoxa-13 and Hoxd-13 play a crucial role in the patterning of the limb autopod. Development 122: 2997-3011.

GOFF, D.J. and TABIN, C.J. (1997). Analysis of Hoxd-13 and Hoxd-11 misexpression in chick limb buds reveals that Hox genes affect both bone condensation and growth. Development 124: 627-36.

GONZÁLEZ-CRESPO, S., ABU-SHAAR, M., TORRES, M., MARTÍNEZ-A, C., MANN, R.S. and MORATA, G. (1998). Antagonism between extradenticle function and Hedgehog signalling in the developing limb. Nature 394: 196-200.

HISA, T., SPENCE, S.E., RACHEL, R.A., FUJITA, M., NAKAMURA, T., WARD, J.M., DEVOR-HENNEMAN, D.E., SAIKI, Y., KUTSUNA, H., TESSAROLLO, L. et al. (2004). Hematopoietic, angiogenic and eye defects in Meis1 mutant animals. EMBO J23: 450-9.

HUANG, H., RASTEGAR, M., BODNER, C., GOH, S.L., RAMBALDI, I. and FEATHERSTONE, M. (2005). MEIS C termini harbor transcriptional activation domains that respond to cell signaling. J Biol Chem 280: 10119-27.

JACOBS, Y., SCHNABEL C.A. and CLEARY M.L. (1999). Trimeric association of Hox and TALE homeodomain proteins mediates Hoxb2 hindbrain enhancer activity. Mol Cell Biol 19:5134-42.

KAMPS, M.P., MURRE, C., SUN, X. and BALTIMORE, D. (1990). A new homeobox gene contributes the DNA binding domain of the $t(1 ; 19)$ translocation protein in pre-B ALL. Ce//60: 547-555.

KILSTRUP-NIELSEN, C., ALESSIO, M. and ZAPPAVIGNA, V. (2003). PBX1 nuclear export is regulated independently of PBX-MEINOX interaction by PKA phosphorylation of the PBC-B domain. EMBO J22: 89-99.

KMITA, M., TARCHINI, B., ZAKANY, J., LOGAN, M., TABIN, C.J. and DUBOULE, D. (2005). Early developmental arrest of mammalian limbs lacking HoxA/HoxD gene function. Nature 435: 1113-6.

KNEZEVIC, V., DE SANTO, R., SCHUGHART, K., HUFFSTADT, U., CHIANG, C., MAHON, K.A. and MACKEM, S. (1997). Hoxd-12 differentially affects preaxial and postaxial chondrogenic branches in the limb and regulates Sonic hedgehog in a positive feedback loop. Development 124: 4523-36

LEHOCZKY, J.A., WILLIAMS, M.E. and INNIS, J.W. (2004). Conserved expression domains for genes upstream and within the HoxA and HoxD clusters suggests a long-range enhancer existed before cluster duplication. Evol Dev6: 423-30.

LIU, Y.H., MA, L., WU, L.Y., LUO, W., KUNDU, R., SANGIORGI, F., SNEAD, M.L. and MAXSON, R. (1994). Regulation of the Msx2 homeobox gene during mouse embryogenesis: a transgene with 439 bp of 5 ' flanking sequence is expressed exclusively in the apical ectodermal ridge of the developing limb. Mech Dev48: 187-97

MAEDA, R., ISHIMURA, A., MOOD, K., PARK, E.K., BUCHBERG, A.M. and DAAR, I.O. (2002). Xpbx1b and Xmeis1b play a collaborative role in hindbrain and neural crest gene expression in Xenopus embryos. Proc Nat/Acad Sci USA 99: 5448-53.

MANN, R.S. and AFFOLTER, M. (1998). Hox proteins meet more partners. Curr Opin Genet Dev 8: 423-9.

MERCADER, N., LEONARDO, E., AZPIAZU, N., SERRANO, A., MORATA, G., MARTINEZ, C. and TORRES, M. (1999). Conserved regulation of proximodistal limb axis development by Meis1/Hth. Nature 402: 425-9.

MERCADER, N., LEONARDO, E., PIEDRA, M.E., MARTINEZ, A.C., ROS, M.A. and TORRES, M. (2000). Opposing RA and FGF signals control proximodistal vertebrate limb development through regulation of Meis genes. Development 127: 3961-70.

MERCADER, N., TANAKA, E.M. and TORRES, M. (2005). Proximodistal identity during vertebrate limb regeneration is regulated by Meis homeodomain proteins. Development 132: 4131-42.

MONICA, K., GALILI, N., NOURSE, J., SALTMAN, D. and CLEARY, M.L. (1991). PBX2 and PBX3, new homeobox genes with extensive homology to the human proto-oncogene PBX1. Mol Cell Biol11: 6149-57.

MORGAN, B.A., IZPISÚA-BELMONTE, J.C., DUBOULE, D. and TABIN, C.J. (1992). Targeted misexpression of Hox-4.6 in the avian limb bud causes apparent homeotic transformations. Nature 358: 236-9.

MOSKOW, J.J., BULLRICH, F., HUEBNER, K., DAAR, I.O. and BUCHBERG, A.M. (1995). Meis1, a PBX1-related homeobox gene involved in myeloid leukemia in BXH-2 mice. Mol Cel/ Biol 15: 5434-43.

NAKAMURA, T., JENKINS, N.A. and COPELAND, N.G. (1996). Identification of a new family of Pbx-related homeobox genes. Oncogene 13: 2235-42.

NELSON, C.E., MORGAN, B.A., BURKE, A.C., LAUFER, E., DIMAMBRO, E., MURTAUGH, L.C., GONZALES, E., TESSAROLLO, L., PARADA, L.F. and TABIN, C. (1996). Analysis of Hox gene expression in the chick limb bud. Development 122: 1449-66.

NOURSE, J., MELLENTIN, J.D., GALILI, N., WILKINSON, J., STANBRIDGE, E. SMITH, S.D. and CLEARY, M.L. (1990). Chromosomal translocation $t(1 ; 19)$ results in synthesis of a homeobox fusion mRNA that codes for a potential chimeric transcription factor. Ce//60: 535-545.

OULAD-ABDELGHANI, M., CHAZAUD, C., BOUILLET, P., SAPIN, V., CHAMBON, P. and DOLLÉ, P. (1997). Meis2, a novel mouse Pbx-related homeobox gene induced by retinoic acid during differentiation of $\mathrm{P} 19$ embryonal carcinoma cells. Dev Dyn 210: 173-83.

POPPERL, H., RIKHOF, H., CHANG, H., HAFFTER, P., KIMMEL, C.B. and MOENS, C.B. (2000). lazarus is a novel pbx gene that globally mediates hox gene function in zebrafish. Mol Cel/6: 255-67.

POST, L.C. and INNIS, J.W. (1999). Altered Hox expression and increased cell death distinguish Hypodactyly from Hoxa13 null mice. Int J Dev Bio/43: 287-94.

PRPIC, N.M., JANSSEN, R., WIGAND, B., KLINGLER, M. and DAMEN, W.G. (2003). Gene expression in spider appendages reveals reversal of exd/hth spatial specificity, altered leg gap gene dynamics, and suggests divergent distal morphogen signaling. Dev Bio/264: 119-40.

RIBES, V., OTTO, D.M., DICKMANN, L., SCHMIDT, K., SCHUHBAUR, B., HENDERSON, C., BLOMHOFF, R., WOLF, C.R., TICKLE, C. and DOLLE, P. (2007). Rescue of cytochrome P450 oxidoreductase (Por) mouse mutants reveals functions in vasculogenesis, brain and limb patterning linked to retinoic acid homeostasis. Dev Bio/303: 66-81.

RIECKHOF, G.E., CASARES, F., RYOO, H.D., ABU-SHAAR, M. and MANN, R.S. (1997). Nuclear translocation of extradenticle requires homothorax, which encodes an extradenticle-related homeodomain protein. Cel/91: 171-83.

SATO, K., KOIZUMI, Y., TAKAHASHI, M., KUROIWA, A. and TAMURA, K. (2007). Specification of cell fate along the proximal-distal axis in the developing chick limb bud. Development 134: 1397-406.

SAUNDERS, J.W. (1948). The proximodistal sequence of origin of the parts of the chick wing and the role of the ectoderm. J. Exp. Zool. 108: 363-403.

SELLERI, L., DEPEW, M.J., JACOBS, Y., CHANDA, S.K., TSANG, K.Y., CHEAH, K.S., RUBENSTEIN, J.L., O'GORMAN, S. and CLEARY, M.L. (2001). Requirement for $\mathrm{Pbx} 1$ in skeletal patterning and programming chondrocyte proliferation and differentiation. Development 128: 3543-57.

SPITZ, F., GONZALEZ, F. and DUBOULE, D. (2003). A global control region defines a chromosomal regulatory landscape containing the HoxD cluster. Cell 113: $405-17$

STADLER, H.S., HIGGINS, K.M. and CAPECCHI, M.R. (2001). Loss of Ephreceptor expression correlates with loss of cell adhesion and chondrogenic capacity in Hoxa13 mutant limbs. Development 128: 4177-88.

SUCOV, H.M., IZPISUA-BELMONTE, J.C., GANAN, Y. and EVANS, R.M. (1995) Mouse embryos lacking $\mathrm{RXR}$ alpha are resistant to retinoic-acid-induced limb defects. Development 121: 3997-4003.

SUMMERBELL, D., LEWIS, J. and WOLPERT, L. (1973). Positional information in chick limb morphogenesis. Nature 224: 492-496.

SUZUKI, M. and KUROIWA, A. (2002). Transition of Hox expression during limb cartilage development. Mech Dev 118: 241-5.

TABIN, C. and WOLPERT, L. (2007). Rethinking the proximodistal axis of the vertebrate limb in the molecular era. Genes Dev 21: 1433-42.

TICKLE, C. (2002). Molecular basis of vertebrate limb patterning. Am JMed Genet 112: $250-5$.

VLACHAKIS, N., CHOE, S.K. and SAGERSTROM, C.G. (2001). Meis3 synergizes 
with $\mathrm{Pbx} 4$ and Hoxb1b in promoting hindbrain fates in the zebrafish. Development 128: 1299-312.

WILKINSON, D.G. and NIETO, M.A. (1993). Detection of messenger RNA by in situ hybridization to tissue sections and whole mount. Methods Enzymol. 225: 361373.

YASHIRO, K., ZHAO, X., UEHARA, M., YAMASHITA, K., NISHIJIMA, M., NISHINO, J., SAIJOH, Y., SAKAI, Y. and HAMADA, H. (2004). Regulation of retinoic acid distribution is required for proximodistal patterning and outgrowth of the developing mouse limb. Dev Ce//6: 411-22.
YOKOUCHI, Y., NAKAZATO, S., YAMAMOTO, M., GOTO, Y., KAMEDA, T., IBA $\mathrm{H}$. and KUROIWA, A. (1995). Misexpression of Hoxa-13 induces cartilage homeotic transformation and changes cell adhesiveness in chick limb buds. Genes Dev 9: 2509-22.

YOKOUCHI, Y., SASAKI, H. and KUROIWA, A. (1991). Homeobox gene expression correlated with the bifurcation process of limb cartilage development. Nature 353: 443-5.

ZAKANY, J. and DUBOULE, D. (1999). Hox genes in digit development and evolution. Cell Tissue Res 296: 19-25.

\section{Related, previously published Int. J. Dev. Biol. articles}

See our recent Special Issue Ear Development edited by Bernd Fritzsch and Fernando Giraldez at: http://www.ijdb.ehu.es/web/contents.php?vol=51\&issue=6-7

See our Special Issue Limb Development edited by Juan Hurle and Juan Carlos Izpisua-Belmonte at: http://www.ijdb.ehu.es/web/contents.php?vol=46\&issue $=7$

PBX proteins: much more than Hox cofactors

Audrey Laurent, Réjane Bihan, Francis Omilli, Stéphane Deschamps and Isabelle Pellerin

Int. J. Dev. Biol. (2008) 52: 9-20

A comparative analysis of Meox1 and Meox 2 in the developing somites and limbs of the chick embryo

Susan Reijntjes, Sigmar Stricker and Baljinder S. Mankoo

Int. J. Dev. Biol. (2007) 51: 753-759

Analysis of a new allele of limb deformity (Id) reveals tissue- and age-specific transcriptional effects of the Ld Global Control Region

Emilia Pavel, Wenning Zhao, Kimerly A. Powell, Michael Weinstein and Lawrence S. Kirschner

Int. J. Dev. Biol. (2007) 51: 273-281

The expression of Fat-1 cadherin during chick limb development Terence G. Smith, Nick Van Hateren, Cheryll Tickle and Stuart A. Wilson Int. J. Dev. Biol. (2007) 51: 173-176

The expression of Flrt3 during chick limb development Terence G. Smith and Cheryll Tickle Int. J. Dev. Biol. (2006) 50: 701-704

PBX1 intracellular localization is independent of MEIS1 in epithelial cells of the developing female genital tract

Agnès Dintilhac, Réjane Bihan, Daniel Guerrier, Stéphane Deschamps, Héloise Bougerie, Tanguy Watrin, Georgette Bonnec and Isabelle Pellerin Int. J. Dev. Biol. (2005) 49: 851-858

Pbx genes are required in Xenopus lens development Richard Morgan, Jastinder Sohal, Mita Paleja and Ruth Pettengell Int. J. Dev. Biol. (2004) 48: 623-627

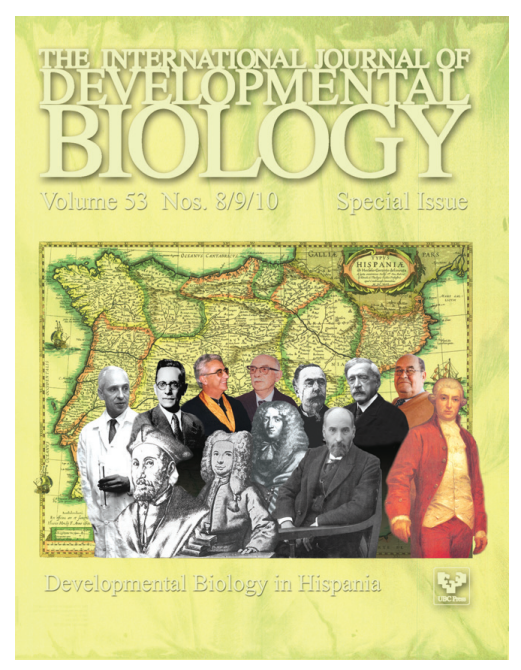

5 yr ISI Impact Factor $(2008)=3.271$

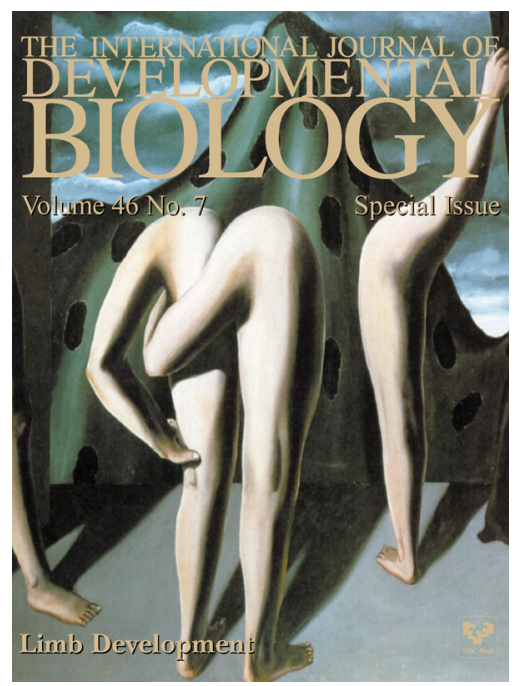

